\title{
Cell death induced by a caspase-cleaved transmembrane fragment of the Alzheimer amyloid precursor protein
}

\author{
I Nishimura ${ }^{1}$, T Uetsuki ${ }^{1}$, K Kuwako', T Hara ${ }^{1}$, T Kawakami ${ }^{2}$, \\ S Aimoto ${ }^{2}$ and K Yoshikawa*,1 \\ ${ }^{1}$ Division of Regulation of Macromolecular Functions, Institute for Protein \\ Research, Osaka University, Yamadaoka 3-2, Suita, Osaka 565-0871, Japan \\ 2 Laboratory of Protein Architectonics, Institute for Protein Research, Osaka \\ University, Yamadaoka 3-2, Suita, Osaka 565-0871, Japan \\ * Corresponding author: K Yoshikawa, Division of Regulation of \\ Macromolecular Functions, Institute for Protein Research, Osaka University, \\ Yamadaoka 3-2, Suita, Osaka 565-0871, Japan. Tel: +81 66879 8621; \\ Fax: +81 66879 8623; E-mail: yoshikaw@protein.osaka-u.ac.jp
}

Received 19.3.01; revised 18.6.01; accepted 13.7.01

Edited by $\mathrm{H}$ Ichijo

\begin{abstract}
The Alzheimer amyloid precursor protein (APP) is a transmembrane protein whose abnormal processing is associated with the pathogenesis of Alzheimer's disease. Activated caspases cleave APP and generate its carboxylterminally truncated fragment (APP $\Delta$ C31). We have previously reported that overexpression of wild-type APP induces caspase-3 activation and apoptosis in postmitotic neurons. We now report that APP $\Delta$ C31 potentially plays pathophysiological roles in neuronal death. Adenovirus-mediated overexpression of wild-type APP695 induced activation of caspase-3 and accumulation of APP $\triangle C 31$ in postmitotic neurons derived from human NT2 embryonal carcinoma cells, whereas an APP mutant lacking the $A \beta(1-20)$ region induced neither caspase-3 activation nor APP $\Delta$ C31 generation. Inhibition of caspase-3 suppressed the generation of APP $\triangle$ C31 in APP-overexpressing neurons. Forced expression of APP $\triangle C 31$ induced apoptotic changes of neurons and non-neuronal cells, but failed to activate caspase-3. The cytotoxicity of APP $\triangle$ C31 was also dependent on the $A \beta(1-20)$ region. These results suggest that accumulation of wild-type APP activates neuronal caspase- 3 to generate APP $\triangle$ C31 that mediates caspase-3-independent cell death.

Cell Death and Differentiation(2002) 9,199-208. DOI: 10.1038/sj/ $\mathrm{cdd} / 4400931$
\end{abstract}

Keywords: amyloid precursor protein; caspase-3; apoptosis; postmitotic neurons; $\mathrm{A} \beta$ domain; Alzheimer's disease

Abbreviations: APP, amyloid precursor protein; AD, Alzheimer's disease; A $\beta, \beta / A 4$; MAP2, microtubule-associated protein $2 ; \beta$-Gal, $\beta$-galactosidase; EthD-1, ethidium homodimer-1; TUNEL, terminal deoxynucleotidyl transferase-mediated dUTP-biotin nick-end labeling; Z-DEVD-FMK, carbobenzoxy-Asp-Glu-Val-Asp-fluoromethylketone; Z-DEVD-AFC, carbobenzoxy-Asp-Glu-Val-Asp-7amino-4-trifluoromethyl coumarin; PCR, polymerase chain reaction; FCS, fetal calf serum

\section{Introduction}

Alzheimer's disease (AD) is a neurodegenerative disease characterized by massive amounts of neuronal death associated with histopathological hallmarks such as extracellular deposition of amyloid fibrils and intracellular accumulation of neurofibrillary tangles. The principal constituent of the amyloid fibrils is $\beta / A 4(A \beta)^{1}$ which is generated by processing of the amyloid precursor protein (APP). APP and $\mathrm{A} \beta$ have been considered as key molecules involved in the pathogenesis of $A D .^{2-5}$ APP695, an APP isoform lacking the protease inhibitor domain, is abundantly expressed in postmitotic neurons during early periods of their differentiation. ${ }^{6}$ However, physiological and pathological roles of APP in neurons remain largely unknown. Earlier studies using APP. deficient cells suggest that cell-associated APP enhances neuronal survival and exerts neuroprotective functions. ${ }^{7,8}$ In contrast, we have previously reported that overexpression of wild-type APP695 induced death of postmitotic neurons derived from murine embryonal carcinoma P19 cells. $^{6}$ Furthermore, viral vector-mediated overexpression of wildtype APP induces apoptosis-like death of postmitotic neurons both in vivo and in vitro. ${ }^{9-12}$ In APP-accumulating neurons in vitro, caspase- 3 is activated in a cleavagedependent manner, and a caspase-3 inhibitor significantly reduces the severity of degeneration exhibited by APPoverexpressing neurons. ${ }^{11}$ These observations suggest that unphysiological levels of wild-type APP induce neuronal apoptosis in a caspase-dependent manner.

Caspases have a regulatory role in programmed death of chick spinal motoneurons, ${ }^{13}$ in which APP expression is upregulated during the course of cell death. ${ }^{14}$ Neurodegenerative insults induce cytoplasmic cleavage of endogenous APP by caspases and generate an APP fragment that lacks the carboxyl (C)-terminal 31-residue region (APP $\Delta$ C31). ${ }^{15}$ Caspase-6, which is activated in apoptotic neurons under serum-deprived conditions, cleaves APP directly at the cytoplasmic domain and generates $\mathrm{A} \beta$ containing fragments. ${ }^{16}$ These findings suggest a close link between APP and the caspase-mediated death machinery.

In this study, we demonstrate that APP $\Delta$ C31 per se exerts cytotoxic effects on human postmitotic neurons and its precursor stem cells. Immunocytochemistry using endspecific antibodies against caspase-cleaved APP fragments revealed that wild-type APP undergoes proteolytic processing into APP $\triangle$ C31 and APP665-695 (APP-C31) when overexpressed in postmitotic neurons. We also show that APP $\Delta$ C31 induces nuclear changes indicative of apoptosis in postmitotic neurons and non-neuronal cells but fails to activate caspase-3. These findings raise the possibility that this caspase-cleaved form of APP has its own role in the modulation of neuronal death. 


\section{Results}

\section{Activation of caspase-3 and generation of APP $\triangle$ C31 in neurons by serum deprivation}

We raised end-specific antibodies against activated caspase-3 subunits (ACP3) and the C-terminus of APP $\triangle$ C31 (SAC) to detect intraneuronal caspase-3 activation and APP $\triangle C 31$ generation. It has been reported that neurodegenerative insults activate neuronal caspases that cleave endogenous APP into APP $\Delta C 31 . .^{15}$ We used postmitotic neurons under serum-deprived conditions to test the specificities and sensitivities of these antibodies (Figure 1). Differentiated neurons, which were identified by staining for the neuronal marker microtubule-associated protein 2 (MAP2), showed apoptotic features such as nuclear fragmentation and condensation by serum deprivation for $96 \mathrm{~h}$. Immunocytochemistry using these antibodies revealed that these apoptotic neurons contained both activated caspase-3 and APP $\triangle$ C 31 . In contrast, MAP2-positive neurons had neither activated caspase-3 nor APP $\triangle$ C31 under serum-supplemented conditions. These data suggest that neuronal caspases are activated by serum-deprivation and cleave endogenous APP at the cytoplasmic domain, and that the endspecific antibodies ACP3 and SAC properly recognize activated caspase- 3 subunits and the C-terminus of APP $\triangle$ C 31 , respectively.

\section{Neuronal caspase-3-activation by accumulation of wild-type APP is dependent on the $\mathrm{A} \beta$ domain}

We infected recombinant adenoviruses expressing wild-type APP and its mutant lacking the $\mathrm{A} \beta(1-20)$ region (APP $\triangle \mathrm{A} \beta 20)$ into neurally differentiated NT2 neurons (Figure 2A). APPaccumulating neurons had condensed, fragmented nuclei and active caspase- 3 subunits $48 \mathrm{~h}$ after infection, whereas a few neurons overexpressing $\mathrm{APP} \triangle \mathrm{A} \beta 20$ or $\beta$-galactosidase $(\beta$ Gal) were positively stained for activated caspase-3. Quantification of caspase-3-immunopositive neurons revealed that $40 \%$ of neurons accumulating wild-type APP contained activated caspase- 3 at $48 \mathrm{~h}$ (Figure 2B). Under these conditions, the population of caspase-3-immunopositive neurons among APP $\triangle \mathrm{A} \beta 20$-accumulating neurons was similar to that of $\beta$-Gal-accumulating neurons $(\sim 10 \%)$. When dead neurons were quantified using ethidium homodimer-1 (EthD-1), a fluorescent dye excluded by viable cells, $36 \%$ of neurons accumulating wild-type APP were found to be dead at $72 \mathrm{~h}$ (Figure $2 \mathrm{C}$ ). In contrast, the population of dead neurons among $\operatorname{APP} \triangle \mathrm{A} \beta 20$-accumulating neurons was $\sim 6 \%$, a level similar to that of $\beta$-Gal-accumulating neurons. These results suggest that the $A \beta(1-20)$ region of APP is required for activation of neuronal caspase-3.

\section{Cleavage of APP at the cytoplasmic site in neurons overexpressing wild-type APP}

Because the cytoplasmic region of wild-type APP695 contains the caspase cleavage site (VEVD), overexpressed full-length APP can be cleaved by caspases into the 664-residue amino (N)-terminal fragment $(\mathrm{APP} \Delta \mathrm{C} 31)$ and the 31-residue C-

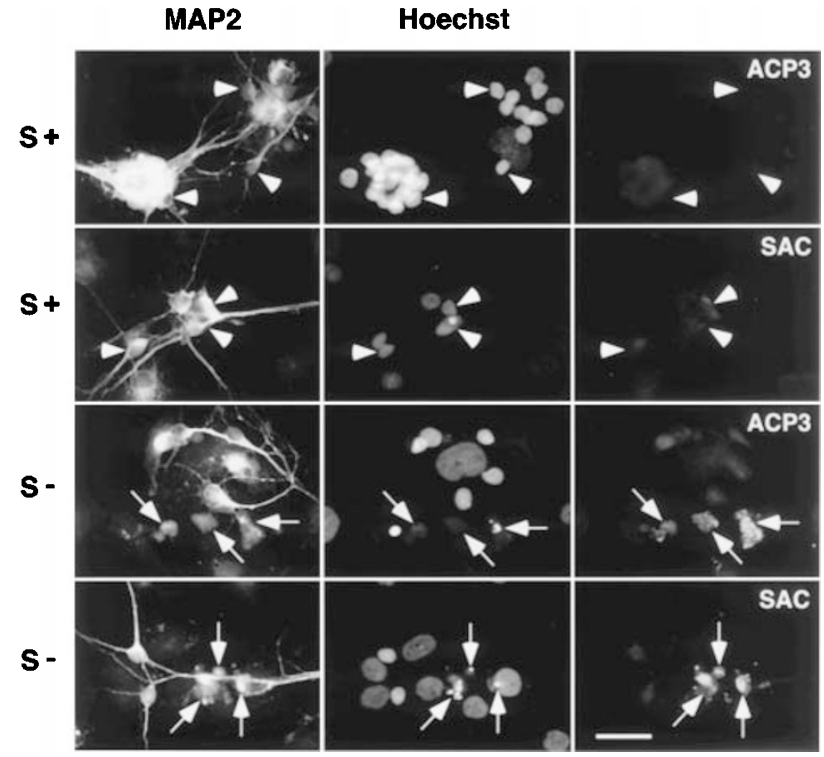

Figure 1 Caspase-3 activation and generation of the caspase-cleaved fragment APP $\triangle \mathrm{C} 31$ within neurons induced by serum deprivation. Neurally differentiated NT2 cells (NT2 neurons) were cultured for $96 \mathrm{~h}$ in the presence $\left(S_{+}\right)$or absence $\left(S_{-}\right)$of $10 \%$ fetal calf serum. Cells were triply labeled for MAP2 (MAP2), chromosomal DNA (Hoechst), and activated caspase-3 subunits (ACP3) [or APP $\triangle C 31$ (SAC)]. MAP2-immunopositive $S$ - neurons with apoptotic nuclei (arrows) are intensely immunostained with ACP3 and SAC, whereas control MAP2-immunopositive $S+$ neurons are hardly stained with these antibodies (arrowheads). Scale bar, $50 \mu \mathrm{m}$

terminal fragment (APP-C31). Using antibodies against the Cterminal end of APP $\triangle \mathrm{C} 31$ (SAC) and the N-terminal end of APP-C31 (ACT1), we examined whether APP $\triangle \mathrm{C} 31$ and APPC31 are actually generated in postmitotic neurons overexpressing wild-type APP. APP-overexpressing NT2 neurons were stained for the $\mathrm{N}$-terminus of APP with antibody P2-1 and chromosomal DNA with Hoechst 33342 (Figure 3A). Most of wild-type APP-accumulating neurons had shrunken and fragmented nuclei. These apoptotic neurons were immunopositive for both APP $\triangle \mathrm{C} 31$ and APP-C31 at $72 \mathrm{~h}$ as judged by staining with $S A C$ and $A C T 1$, respectively. In contrast, APP $\triangle$ C31 and APP-C31 were hardly detected in APP$\triangle \mathrm{A} \beta 20$-accumulating neurons or APP-accumulating nonneuronal cells in the mixed cultures.

To examine whether caspase- 3 is involved in the cleavage of APP at the cytoplasmic site, we treated APPoverexpressing neurons with the cell permeable caspase-3 inhibitor carbobenzoxy-Asp-Glu-Val-Asp-fluoromethylketone (Z-DEVD-FMK) and examined the generation of APP $\triangle$ C31 and APP-C31 with the end-specific antibodies SAC and ACT1 (Figure 3B). In the absence of the inhibitor, $44 \%$ and $29 \%$ of APP-accumulating neurons were found to be immunopositive for SAC and ACT1 immunoreactivities, respectively. In the presence of the inhibitor $(150 \mu \mathrm{M})$, the proportions of APP $\triangle$ C 31 - and APP-C31-accumulating neurons were significantly decreased to $18 \%$ and $13 \%$, respectively. The inhibitor had no appreciable effects on the proportions of SAC- and ACT1-immunopositive neurons that overexpressed APP $\triangle \mathrm{A} \beta 20$. These results suggest that activated caspase- 3 caused by intracellular accumulation 
A

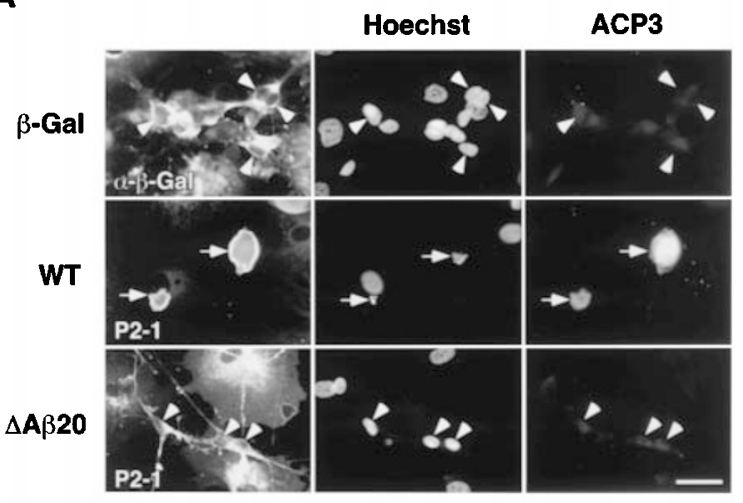

B

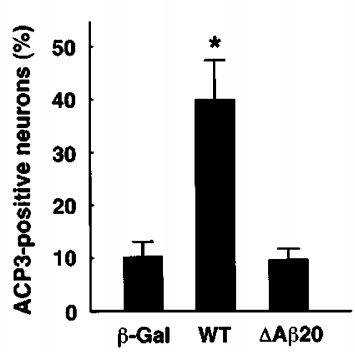

C

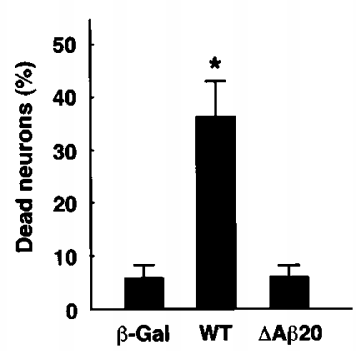

Figure 2 Caspase-3 activation in neurons accumulating wild-type APP and the mutant lacking the $\mathbf{A} \beta(1-20)$ domain. (A) Immunocytochemistry for APP, chromosomal DNA, and activated caspase-3 subunits. NT2 neurons were infected with AxCALacZ ( $\beta$-Gal), AxCAYAP (WT), or AxCAP $\triangle A \beta 20(\triangle \mathrm{A} \beta 20)$, fixed $48 \mathrm{~h}$ later, and triply stained for the $\mathrm{N}$-terminus of APP (P2-1) (or $\beta$-Gal), chromosomal DNA (Hoechst), and activated caspase-3 subunits (ACP3). Some neurons accumulating wild-type APP are strongly immunostained with ACP3 (arrows), with which neurons accumulating APP $\triangle \mathrm{A} \beta 20$ and $\beta$-Gal are hardly labeled (arrowheads). Scale bar, $50 \mu \mathrm{m}$. (B) Quantification of activated caspase-3-immunopositive neurons. NT2 neurons were infected with each recombinant adenovirus and fixed $48 \mathrm{~h}$ later for staining with ACP3. ACP3immunopositive cells among APP (or $\beta$-Gal)-immunopositive neurons were counted (mean \pm s.e.m., $n=3 ; \geqslant 200$ cells per each group). ${ }^{\star} P<0.05$, significantly different from the values of cells accumulating $\beta$-Gal or $\Delta \mathrm{A} \beta 20$. (C) Quantification of neuron death. NT2 neurons were infected with each adenovirus, labeled with EthD-1 $72 \mathrm{~h}$ later, and immunostained for APP or $\beta$ Gal. EthD-1-positive cells among APP (or $\beta$-Gal)-immunopositive neurons were counted (mean \pm s.e.m., $n=4 ; \geqslant 100$ cells per each group). ${ }^{*} P<0.05$, significantly different from the values of cells accumulating $\beta$-Gal or $\Delta \mathrm{A} \beta 20$

of wild-type APP substantially cleaves APP at the cytoplasmic site.

Western blot analysis revealed that wild-type APP and mutant proteins were abundantly expressed as analyzed using antibodies against the C-terminus of APP (AC1) (Figure 4A) and the $\mathrm{N}$-terminus (AN2) (Figure 4B, upper panel). Neurons overexpressing wild-type APP contained a $96 \mathrm{kDa}$ SAC-immunoreactive fragment, which was detected in APP $\triangle$ C31-overexpressing neurons (Figure 4B, lower panel). The amount of APP $\triangle \mathrm{C} 31$ in neurons overexpressing wild-type APP was similar to that in neurons overexpressing APP $\triangle$ C31, suggesting that a considerable amount of wildtype APP is processed into APP $\triangle$ C 31 . In contrast, APP $\triangle$ C31 was undetected in neurons overexpressing
A
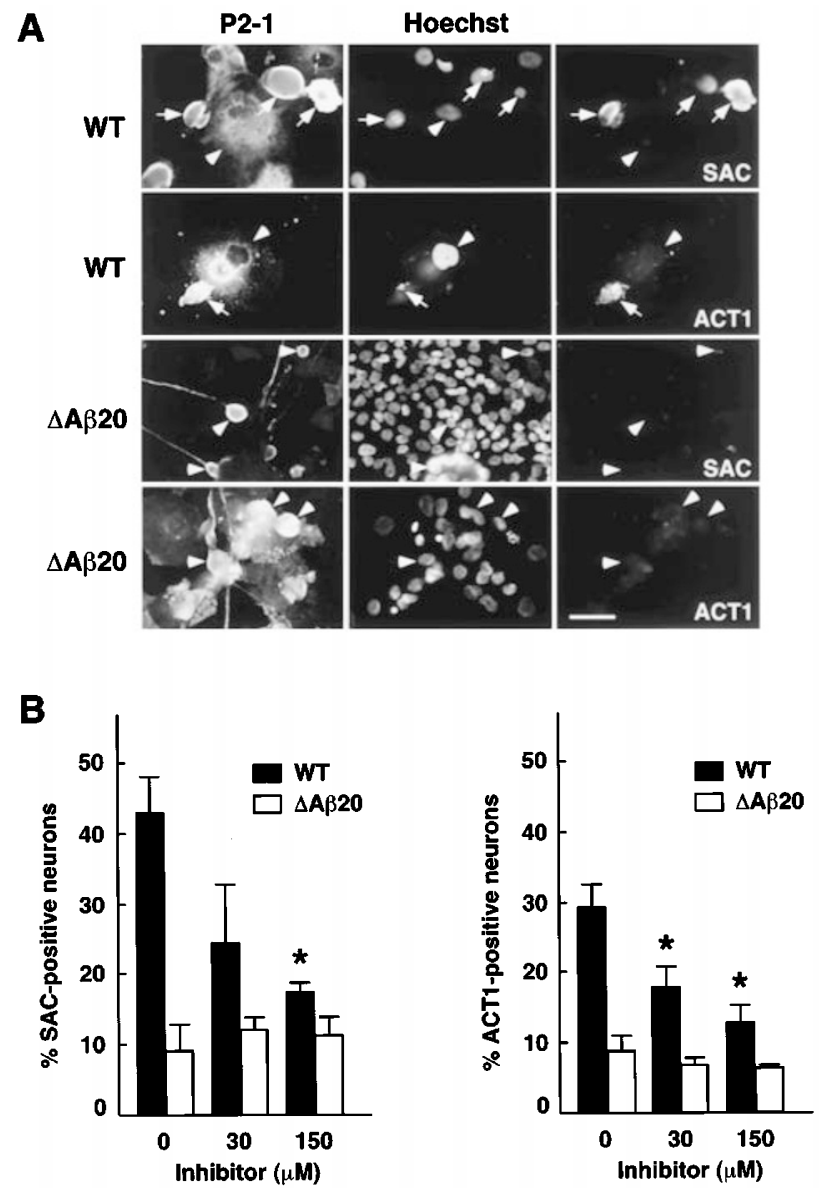

Figure 3 Generation of the caspase-cleaved fragments in NT2 neurons overexpressing wild-type APP. (A) Immunocytochemistry for APP $\triangle$ C31 and APP-C31. NT2 neurons were fixed $72 \mathrm{~h}$ after infection with AxCAYAP (WT) or $\operatorname{AxCAP} \triangle \mathrm{A} \beta 20(\triangle \mathrm{A} \beta 20)$, and stained for the $\mathrm{N}$-terminus of APP (P2-1), chromosomal DNA (Hoechst), and the C-terminus of APP $\triangle \mathrm{C} 31$ (SAC) [or the $\mathrm{N}$-terminus of APP-C31 (ACT1)]. Most of wild-type APP-accumulating neurons with shrunken and fragmented nuclei contain SAC- and ACT1-immunoreactivities (arrows), but non-neuronal cells infected with AxCAYAP and neurons infected with $\operatorname{AxCAP} \triangle \mathrm{A} \beta 20$ are hardly labeled with SAC and ACT1 (arrowheads). Scale bar, $50 \mu \mathrm{m}$. (B) Quantification of APP $\triangle$ C31- and APPC31-immunopositive neurons treated with a caspase-3 inhibitor. NT2 neurons were cultured in the presence of the caspase-3 inhibitor Z-DEVD-FMK after infection with AxCAYAP (WT) or AxCAP $\triangle \mathrm{A} \beta 20(\triangle \mathrm{A} \beta 20)$. Cells were fixed at $72 \mathrm{~h}$ and stained for the $\mathrm{N}$-terminus of APP (P2-1) and the C-terminus of APP $\triangle C 31$ (SAC) or the N-terminus of APP-C31 (ACT1). SAC- and ACT1immunopositive neurons among P2-1-positive neurons were counted (mean \pm s.e.m., $n=3 ; \geqslant 50$ cells per each group). ${ }^{\star} P<0.05$, significantly different from the values of cells cultured in the absence of Z-DEVD-FMK

APP $\triangle \mathrm{A} \beta 20$ or $\beta$-Gal. These results, together with the data shown in Figures 2 and 3, suggest that overexpression of wild-type APP activates neuronal caspases that eventually cleave APP at the cytoplasmic site.

We have previously shown that a C-terminal 100 amino acid fragment of APP (APP-C100), which encompasses the $\mathrm{A} \beta$ domain and the $\mathrm{C} 31$ region, forms amyloid fibril-like structures in cDNA-transfected COS cells. ${ }^{17}$ We then examined whether full-length APP self-associates when accumulated on the membrane. Cell surface proteins in 
NT2 neurons infected with recombinant adenoviruses expressing $\beta$-Gal, wild-type APP, APP $\Delta \mathrm{A} \beta 20$ and APP $\triangle$ C31 were treated with a membrane-impermeable cross-linker and analyzed by Western blotting using the antibody against the N-terminus of APP (AN2) (Figure 4C). APP immunoreactive bands were detected at $\sim 110 \mathrm{kDa}$ and $>220 \mathrm{kDa}$. The $>220 \mathrm{kDa}$ bands, which may correspond to APP cross-linked with other membrane proteins, were undetected in the absence of the crosslinker (data not shown). Only the neurons overexpressing wild-type APP contained a distinct $\sim 220 \mathrm{kDa}$ APP immunoreactive band, whose size corresponds to that of the APP homodimer. These results suggest that the transmembrane form of APP tend to self-associate when concentrated on the membrane.

\section{Caspase-3-independent neuronal death induced by APP $\triangle$ C31}

Because APP $\triangle$ C31 was generated in neurons overexpressing wild-type APP, we then examined whether APP $\Delta$ C31 per se affects neuronal viability. We constructed the adenovirus vector expressing APP $\Delta \mathrm{C} 31(\mathrm{AxCAP} \Delta \mathrm{C} 31)$ and infected it into NT2 neurons (Figure 5). A number of APP $\triangle \mathrm{C} 31$ expressing neurons underwent death as analyzed by EthD1 retention test (top panels). These degenerated neurons had nuclei stained positively by terminal deoxynucleotidyl transferase-mediated dUTP-biotin nick-end labeling (TUNEL) (middle panels). Intriguingly, APP $\Delta$ C31-accumulating neurons carrying apoptotic nuclei contained little or no activated caspase-3-immunoreactivity (bottom panels). These results suggest that APP $\triangle \mathrm{C} 31$ induces neuronal apoptosis in a caspase-3-independent manner.

Quantification of neuron death by the EthD-1 retention assay revealed that $28 \%$ of $\mathrm{APP} \Delta \mathrm{C} 31$-expressing neurons were dead. Under the same conditions, $\beta$-Gal and wildtype APP caused neuron death at $7 \%$ and $33 \%$, respectively (Figure 6A). We then measured caspase-3like protease activity in neurons overexpressing wild-type $\mathrm{APP}, \mathrm{APP} \triangle \mathrm{C} 31, \mathrm{APP} \triangle \mathrm{A} \beta 20$, or $\beta$-Gal using the fluorogenic substrate carbobenzoxy-Asp-Glu-Val-Asp-7-amino-4trifluoromethyl coumarin (Z-DEVD-AFC) (Figure 6B). In agreement with the immunocytochemical data shown in Figures $2 \mathrm{~A}$ and 5, caspase-3-like activities in APP $\Delta \mathrm{C} 31$, APP $\triangle \mathrm{A} \beta 20$, and $\beta$-Gal-overexpressing neurons remained low during the 96-h incubation period, whereas the activity in wild-type APP-overexpressing neurons increased and reached a peak at $48 \mathrm{~h}$.

\section{Cytotoxicity of APP $\triangle \mathrm{C} 31$ is not specific to postmitotic neurons}

We have previously shown that caspase-3-mediated apoptosis by wild-type APP is specific to postmitotic neurons. ${ }^{11}$ The present study has shown that APP $\triangle$ C31 induced caspase-3independent neuronal death. These findings suggested that APP $\triangle$ C31 induces apoptosis in a manner distinct from that of wild-type APP. When NT2 embryonal carcinoma stem cells (NT2S) and differentiated neurons (NT2N) were infected with the adenovirus vector expressing APP $\Delta$ C31, some of the

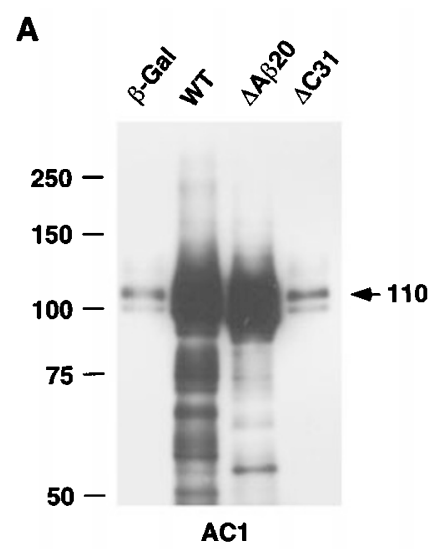

B
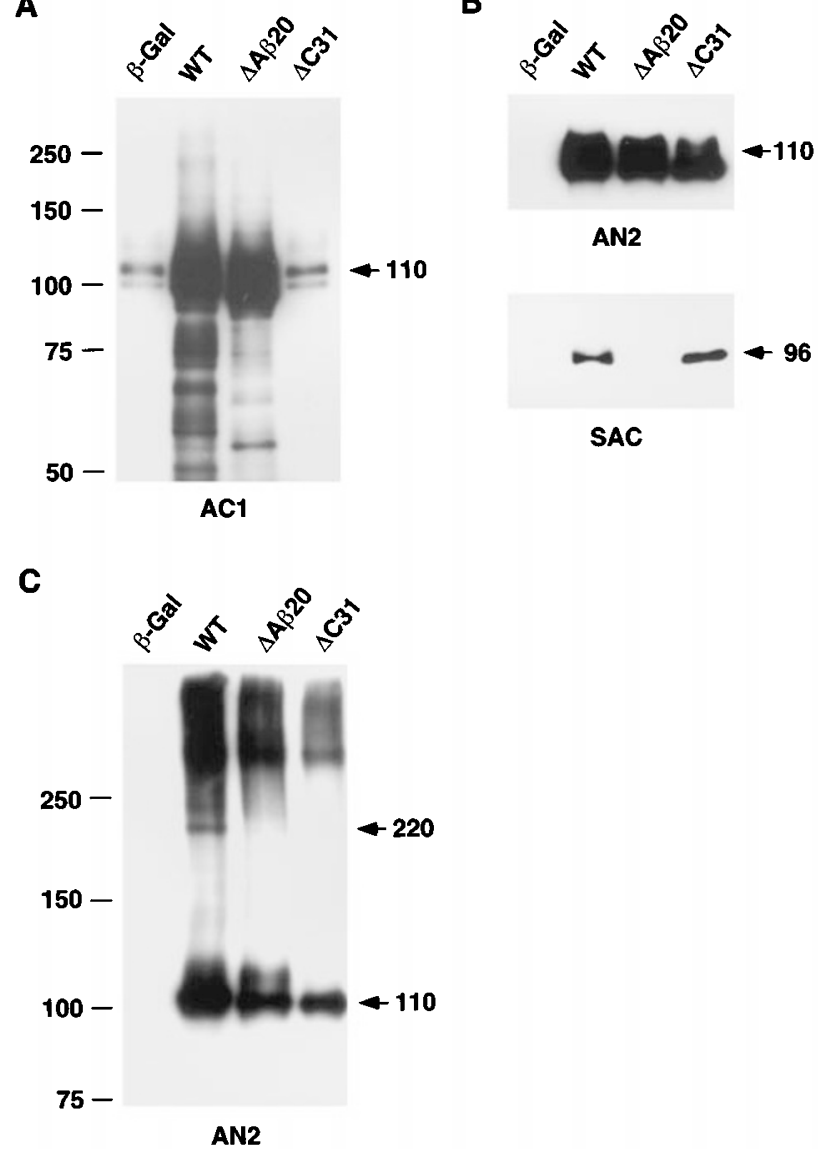

Figure 4 Western blot analysis of APP, APP $\triangle \mathrm{A} \beta 20$ and APP $\triangle \mathrm{C} 31$. NT2 neurons were infected with AxCALacZ ( $\beta$-Gal), AxCAYAP (WT), AxCAP $\triangle \mathrm{A} \beta 20$ $(\triangle \mathrm{A} \beta 20)$, or $\mathrm{AxCAP} \Delta \mathrm{C} 31(\triangle \mathrm{C} 31)$. Cell lysates were prepared $48 \mathrm{~h}$ after infection, and proteins were analyzed by Western blotting. (A) The APP Cterminus immunoreactivity (AC1). (B) APP N-terminus immunoreactivity (AN2; upper panel), and the C-terminal end of APP $\triangle \mathrm{C} 31$ (SAC; lower panel). (C) A cross-linking experiment for cell surface proteins. Infected neurons were incubated with the cross-linker bis (sulfosuccinimidyl) suberate, and proteins in cell lysates were analyzed by Western blotting using antibody AN2. Molecular weight markers are indicated at the left (in kilodaltons) (A, C). Arrows, molecular sizes of reference bands in kilodaltons

stem cells and neurons showed apoptotic changes and EthD1 retention (Figure 7). In contrast, most of the stem cells overexpressing wild-type APP were morphologically intact and showed little or no EthD-1 retention.

We then quantified the cytotoxic effects of $\beta$-Gal, APP $\triangle$ C31, wild-type APP, and APP $\triangle A \beta 20$ on NT2 stem cells and transformed cell lines (Figure 8A). Only APP $\triangle \mathrm{C} 31$ caused a significant increase in the dead population of nonneuronal cells such as NT2 stem cells, African green monkey kidney COS-1 cells, human glioma Bu17 cells, and human cervical carcinoma HeLa cells. The cytotoxic effects of wild-type APP and APP $\triangle \mathrm{A} \beta 20$ were hardly detected in these non-neuronal cells as compared with the values of the negative control of $\beta$-Gal $(P>0.05)$. In contrast, the cytotoxic effect of wild-type APP was seen only in NT2 neurons. These results indicate that APP $\triangle \mathrm{C} 31$, unlike wildtype APP, is cytotoxic to non-neuronal cells as well as to postmitotic neurons. 
P2-1
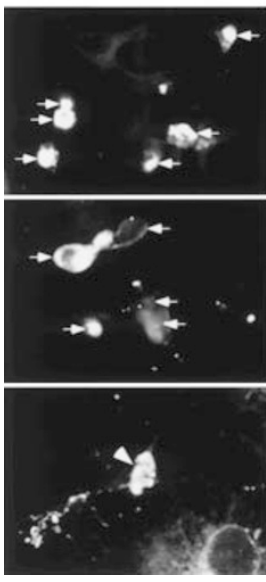

Figure 5 Caspase-3-independent neuronal death induced by APP $\triangle \mathrm{C} 31$ NT2 neurons were infected with AxCAP $\Delta$ C 31 , fixed $72 \mathrm{~h}$ later, and analyzed for cell death (top panels) and DNA fragmentation (middle panels). Cells were labeled for the N-terminus of APP (P2-1), chromosomal DNA (Hoechst), and EthD-1 (EthD-1) (or TUNEL). Some of the APP $\triangle$ C31accumulating neurons showing nuclear abnormalities are positively labeled with EthD-1 and TUNEL (arrows). Cells were also fixed $48 \mathrm{~h}$ after infection with AxCAP $\triangle \mathrm{C} 31$ and stained for activated caspase-3 subunits (ACP3) (bottom panels). APP $\triangle \mathrm{C} 31$-accumulating neurons have condensed nuclei, severe membrane blebbing, and dystrophic neurites, but are negative for activated caspase- 3 (arrowheads). Scale bar, $50 \mu \mathrm{m}$ for top and middle panels; $25 \mu \mathrm{m}$ for bottom panels
A

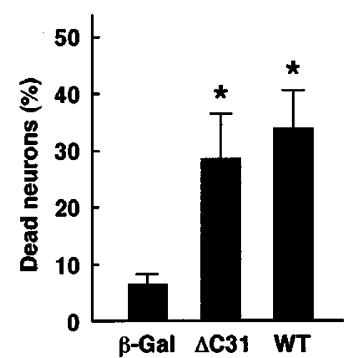

B

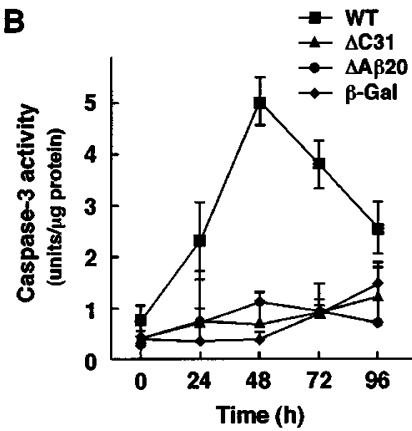

Figure 6 Lack of caspase-3-activation in neuron death induced by APP $\triangle$ C31. (A) Quantification of neuron death. NT2 neurons were infected with AxCALacZ ( $\beta$-Gal), AxCAP $\triangle \mathrm{C} 31$ ( $\Delta \mathrm{C} 31)$, or AxCAYAP (WT). Cells were fixed $72 \mathrm{~h}$ later for EthD-1 retention assay. EthD-1-positive cells among APPor $\beta$-Gal-positive neurons were counted (mean \pm s.e.m., $n=4 ; \geqslant 100$ cells per each group). ${ }^{*} P<0.05$, significantly different from the value of $\beta$-Galaccumulating cells. (B) Caspase-3-like protease activity in infected NT2 neurons. NT2 neurons were infected with AxCAYAP (WT), AxCAP $\triangle \mathrm{C} 31$ $(\triangle \mathrm{C} 31), \operatorname{AxCAP} \triangle \mathrm{A} \beta 20(\triangle \mathrm{A} \beta 20)$, or $\mathrm{AxCALacZ}(\beta$-Gal), and caspase-3-like protease activity in the cell lysate was measured using the fluorogenic substrate Z-DEVD-AFC (mean \pm s.e.m., $n=3$ )

In order to examine whether the $\mathrm{A} \beta(1-20)$ domain in APP $\triangle$ C31 is responsible for its cytotoxicity, we constructed a vector expressing an APP mutant lacking both the $\mathrm{A} \beta(1-$ 20) and C-terminal 31-residue regions (termed APP $\triangle \mathrm{A} \beta 20$ / C31) and transfected it into COS-1 cells. The EthD-1 retention assay revealed that $32 \%$ of APP $\Delta$ C 31 -expressing cells were dead (Figure $8 \mathrm{~B}$ ). In this assay system, the

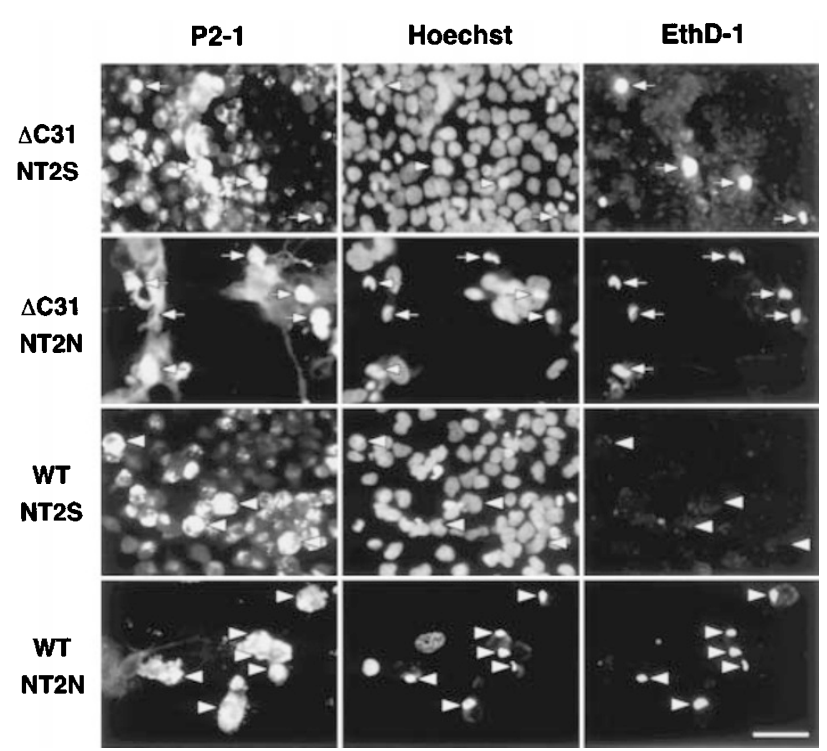

Figure 7 APP $\triangle \mathrm{C} 31$-induced death of NT2 stem cells. NT2 stem cells (NT2S) and differentiated NT2 neurons (NT2N) were infected with AxCAP $\triangle$ C31 $(\triangle \mathrm{C} 31)$ or AxCAYAP (WT), fixed $72 \mathrm{~h}$ later, and triply labeled for the $\mathrm{N}$ terminus of APP (P2-1), chromosomal DNA (Hoechst), and cell viability (EthD1). APP $\triangle \mathrm{C} 31$ is toxic to both NT2 stem cells and NT2 neurons (arrows), but only neurons undergo death by wild-type APP (arrowheads). Scale bar, $50 \mu \mathrm{m}$

cytotoxic level of APP $\triangle \mathrm{A} / 20 / \mathrm{C} 31$ was similar to those ( $\sim 15 \%$ dead cells) of wild-type APP, $\beta$-Gal and APP$\triangle \mathrm{A} \beta 20$, which showed only the non-specific viral cytotoxicity. These findings suggest that the $A \beta(1-20)$ region of APP $\triangle$ C31 is indispensable for its cytotoxity.

\section{Discussion}

\section{Caspase-3-independent apoptosis induced by APP $\triangle$ C31}

Recent studies have demonstrated that APP is cleaved by caspases at Asp 664. ${ }^{14-16,18-20}$, The present immunocytochemical study has shown that apoptotic neurons under serum-deprived conditions contained activated caspase-3 subunits and APP $\triangle$ C31 (Figure 1). Furthermore, both APP $\triangle$ C31 and APP-C31 were detected in neurons overexpressing wild-type APP (Figure $3 \mathrm{~A}$ ). Generation of these fragments were significantly suppressed by treatment with caspase-3 inhibitor (Figure 3B). These findings suggest that overexpression of wild-type APP causes activation of caspases that subsequently cleave APP at the cytoplasmic Asp664 site (Figures 2A,B and 6B). Intriguingly, APP $\Delta$ C31 per se caused apoptosis of neurons in a caspase-3independent manner (Figures 5 and 6). We also found that overexpression of APP $\triangle \mathrm{C} 31$ caused death of non-neuronal cells including proliferative neural precursor cells and transformed cell lines originating from non-neuronal tissues (Figures 7 and $8 \mathrm{~A}$ ), indicating that the cytotoxic effects of APP $\triangle$ C31 are independent of cell species and their differentiation states. APP-C31, which is the counterpart of APP $\triangle$ C31 generated by caspase cleavage, has recently been reported to act as a cytotoxic peptide in cells treated with 
A

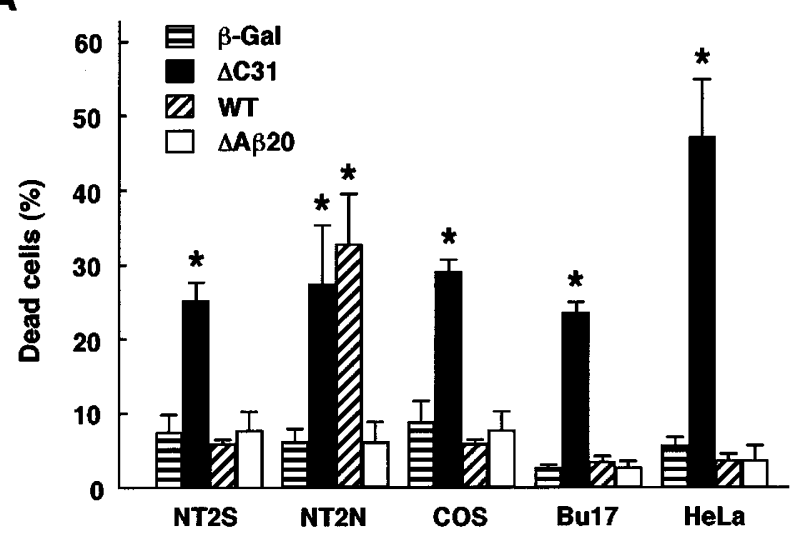

B

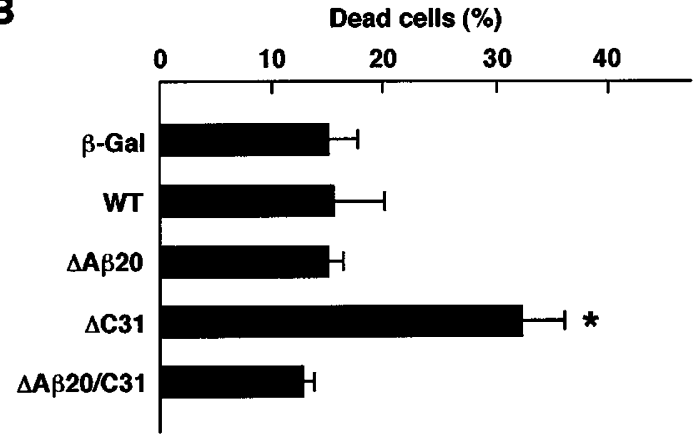

Figure 8 Quantification of APP $\triangle$ C31-induced cytotoxicity. (A) APP $\triangle$ C31induced cell death of NT2 cells and transformed cell lines. NT2 stem cells (NT2S), NT2 neurons (NT2N), COS-1 (COS), Bu17 glioma (Bu17), and HeLa cervical carcinoma (HeLa) cells were infected with AxCALacZ ( $\beta$-Gal), AxCAP $\triangle C 31$ ( $\triangle \mathrm{C} 31$ ), AxCAYAP (WT), or AxCAP $\triangle A \beta 20(\triangle \mathrm{A} \beta 20)$. Cells were fixed $72 \mathrm{~h}$ (for NT2S and NT2N cells) and $48 \mathrm{~h}$ (for COS, Bu17 and HeLa cells) after infection and double labeled with P2-1 (or $\beta$-Gal) and EthD-1. EthD-1 positive cells among P2-1(or $\beta$-Gal)-positive cells were counted (mean \pm s.e.m., $n=3 ; \geqslant 100$ cells per each group). ${ }^{*} P<0.05$, significantly different from the values of cells accumulating $\beta$-Gal. (B) Absence of cytotoxicity of the double-deletion mutant APP $\triangle \mathrm{A} \beta 20 / \mathrm{C} 31$. COS-1 cells were transfected with pcDNA3.1 vectors carrying LacZ ( $\beta$-Gal), wild-type APP (WT), APP $\triangle A \beta 20$ $(\triangle \mathrm{A} \beta 20)$, APP $\Delta \mathrm{C} 31(\triangle \mathrm{C} 31)$, and $\mathrm{APP} \triangle \mathrm{A} \beta 20 / \mathrm{C} 31(\triangle \mathrm{A} \beta 20 / \mathrm{C} 31) \mathrm{cDNAs}$. Cells were fixed $72 \mathrm{~h}$ after transfection and double labeled with P2-1 (or $\beta$-Gal) and EthD-1. EthD-1-positive cells among P2-1 (or $\beta$-Gal)-positive cells were counted (mean \pm s.e.m., $n=3 ; \geqslant 200$ cells per each group). ${ }^{*} P<0.05$, significantly different from the values of $\beta$-Gal control

apoptosis-inducing agents. ${ }^{20}$ Thus, it is inferred that proteolytic processing of APP by caspases concomitantly generates APP $\triangle$ C31 and APP-C31 that exert their effects on cell death.

The molecular mechanisms whereby APP $\triangle$ C 31 causes apoptotic cell death remain to be elucidated. Activated caspase-3 was undetected in neurons overexpressing APP $\triangle \mathrm{C} 31$ (Figures 5 and $6 \mathrm{~B}$ ). Furthermore, we were unable to detect the activation of other caspases such as caspases-7, $-6,-8$, and -9 or upregulation of the endoplasmic reticulum stress marker proteins such as Grp78 and GADD153 (I Nishimura and K Yoshikawa, unpublished observations). The APP $\triangle$ C 31 -induced cytotoxicity has previously been assessed using mouse neuroblastoma cells treated with the apoptosisinducing compounds staurosporine and tamoxifen. ${ }^{20}$

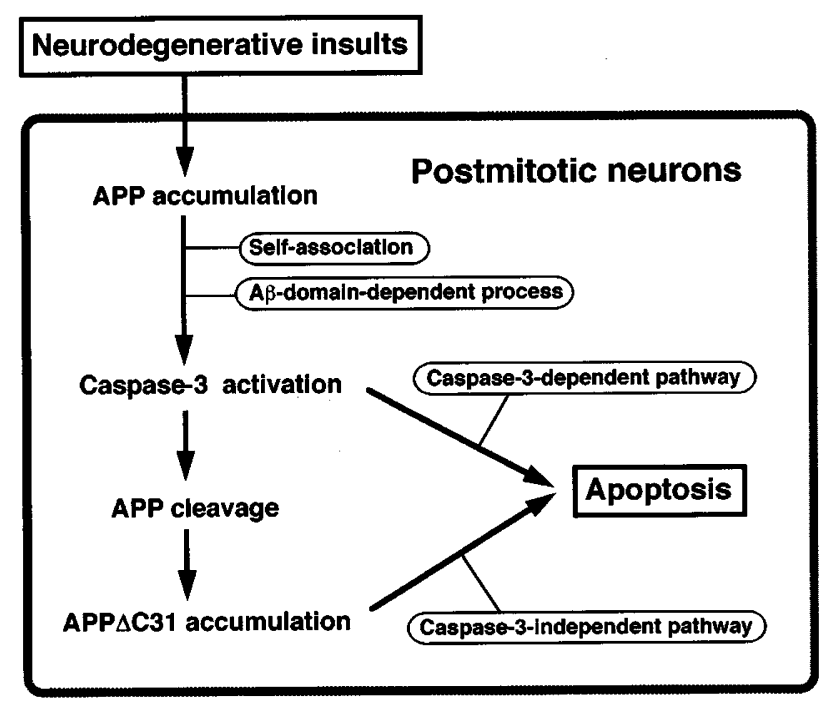

Figure 9 A schematic model of the roles of APP and APP $\triangle$ C31 in neuronal apoptosis. See Discussion for details

APP $\triangle$ C 31 had no cytotoxic effects on the neuroblastoma cells treated with staurosporine. However, they also reported that APP $\triangle$ C31 significantly reduced the cell viability when treated with tamoxifen. We have found that rodent cells require higher titers of APP-expressing adenoviruses than primate cells to undergo similar changes. We thus used primate cell lines infected with lower titers of adenovirus to demonstrate the cytotoxic effects of APP and APP $\triangle$ C 31 in the present study. Thus we infer that cytotoxicity of APP $\triangle$ C 31 is dependent on various factors such as cell types, APP $\Delta$ C 31 expression levels, and presence of other cytotoxic agents.

In APP-overexpressing neurons, APP and subsequently generated APP $\triangle$ C31 would show additive or cooperative toxicity because they both have cytotoxic effects. However, we found that the neurotoxic potency of wild-type APP was similar to that of APP $\triangle$ C31 (Figure 6A). We used adenovirus titers that show a dead population of $\sim 30 \%$ among total infected cells, because higher titers exert nonspecific toxicity as generally observed in the adenovirus gene transfer system. Under these conditions, each infected neuron responds to APP with either death or survival. Thus, the fate of each APP-accumulating neuron cannot be changed even when cytotoxic APP $\Delta$ C 31 is generated within the same cell. We speculate that this is the reason why wild-type APP (plus endogenously generated APP $\triangle$ C31) and APP $\triangle C 31$ showed similar cytotoxic potencies.

Some intracellular proteins have been reported to gain pathophysiological functions when cleaved by caspases. For example, Acinus and transcription factor NRF2 are cleaved by caspases and their cleaved products function as effectors for apoptosis. ${ }^{21,22}$ Furthermore, tau, a microtubule-associated protein whose abnormal phosphorylation is thought to cause formation of neurofibrillary tangles seen in $A D$, is cleaved by caspase-3 in vitro, and overexpression of the caspase-cleaved $\mathrm{N}$-terminal fragment of tau induces apoptosis of NT2 stem cells and COS cells. ${ }^{23,24}$ These 
findings, together with our present findings, raise the possibility that caspase-cleaved products of endogenous APP and tau, whose posttranslational modifications are believed to be involved in the pathogenesis of $A D$, directly induce neuronal death.

\section{Neuronal specificity of caspase-mediated apoptosis induced by wild-type APP}

Overexpression of wild-type APP causes caspase-3mediated apoptosis of postmitotic neurons but not of nonneuronal cells, ${ }^{11}$ suggesting that a neuron-specific machinery is involved in APP-induced caspase-3 activation. It has been demonstrated that two adaptor proteins, mammalian Disabled and FE65, which are primarily expressed in neurons, interact with the cytoplasmic tail of APP that contains the adaptor protein-binding motif NPTY. ${ }^{25}$ This suggests that APP acts as a neuronal surface receptor that mediates intracellular signal transduction. Thus, APP-binding adaptor proteins such as Disabled and FE65 may contribute to the neuronal specificity of APP-induced caspase-3 activation. This idea is supported by the present findings that APP $\triangle \mathrm{C} 31$, which lacks the adaptor-binding $\mathrm{C} 31$ region, failed to activate caspase-3 (Figures 5 and 6B). Another possibility is that neuron-specific ion channels or neurotransmitter receptors are involved in APP-induced neuronal apoptosis. We have previously reported that wild-type APP increases glutamate-induced $\mathrm{Ca}^{2+}$ influx into neuronal cytoplasm. ${ }^{26}$ Furthermore, we have recently found that APP causes elevation of intracellular $\mathrm{Ca}^{2+}$ levels in postmitotic neurons prior to caspase- 3 activation (manuscript in preparation). These findings suggest that $\mathrm{Ca}^{2+}$ channels or molecules regulating $\mathrm{Ca}^{2+}$ channel activities are involved in caspase- 3 activation caused by wild-type APP.

Transgenic mice carrying APP mutants such as APP (Val717Phe) $^{27}$ and APP695 (Lys670Asn/Met671Leu) ${ }^{28}$ have been reported to show neuropathological changes accompanied by extracellular $\mathrm{A} \beta$ depositions. However, no overt neuronal loss is detected in the brain regions in which $A \beta$ is extensively deposited in APP (Val717Phe) transgenic mice, ${ }^{29}$ suggesting that extracellular $\mathrm{A} \beta$ deposits per seare not toxic to neurons. The APP mutants in the transgenic mice in vivo may not be accumulated to toxic levels within neurons, whereas adenovirus-mediated overexpression of wild-type APP in vivo and in vitro induces a rapid elevation of APP levels sufficient for neuronal caspase-3 activation. ${ }^{10,11}$

\section{Self-association of APP may be responsible for caspase-3 activation}

It is noteworthy that the APP mutant lacking the $\mathrm{A} \beta(1-20)$ domain (APP $\triangle A \beta 20$ ), like APP $\triangle C 31$, induced no neuronal caspase- 3 activation (Figures $2 A, B$ and $6 B$ ). These findings suggest that both the $A \beta$ domain and the cytoplasmic C31 region are indispensable for caspase-3 activation. We have previously reported that a C-terminal 100 amino acid fragment of APP, termed APP-C100, forms amyloid fibril-like structures in cDNA-transfected COS cells. ${ }^{17}$ APP-C100 which encompasses the $\mathrm{A} \beta$ and cytoplasmic $\mathrm{C} 31$ regions, is neurotoxic in vitro and in vivo. ${ }^{5}$ Thus, we speculate the self-associating nature of the C-terminal region of APP is responsible for the caspase-3 activation and neuronal death. The cross-linking experiment revealed that wild-type APP-overexpressing neurons contained the $\sim 220 \mathrm{kDa}$ APP-immunoreactive band (Figure 4C), suggesting that wild-type APP, which comprises intact APP-C100 region, is prone to self-associate to form homodimer when accumulated on the membrane. It has recently been reported that antibodies against subsequences of the extracellular APP domain induce neuronal apoptosis. $^{30,31}$ A monoclonal antibody (22C11) against the extracellular APP66-81 region induces caspase-3 activation and apoptosis in neurons, suggesting that the antibody facilitates APP dimerization and activates the caspase pathway. ${ }^{30}$ Furthermore, we confirmed that antibody 22C11 induced caspase-3 activation and apoptosis in NT2 neurons within $24 \mathrm{~h}$ (I Nishimura and K Yoshikawa, unpublished observations). These findings together suggest that self-association of APP on the cell surface triggers the caspase cascade in neuronal cytoplasm.

\section{Pathophysiological implications of APP-induced neuronal death}

Based on the present findings, we schematized our hypothesis for APP-induced events operative in postmitotic neurons (Figure 9). Earlier studies have revealed that pathological stimuli and trophic factor deprivation upregulate endogenous APP levels. ${ }^{14,32,33}$ Furthermore, histopathological studies have revealed that neurons in $A D$ brain contain abnormally dense APP-immunoreactive materials. ${ }^{34-36}$ Thus, neurons may have a propensity to accumulate APP in response to various insults ranging from trophic factor deprivation to neurotoxic stimuli. This phenomenon can be a compensatory response of stressed neurons to protect themselves against degeneration because cell-associated APP possesses neuroprotective functions. ${ }^{7,8}$ When the amounts of APP accumulations in affected neurons reach abnormally high levels, APP may in turn start to self-associate and activate caspases. Neuron-specific machinery including intracellular signal transduction molecules, ion channels, or neurotransmitter receptors may be involved in caspase activation. The caspase-cleaved transmembrane fragment APP $\Delta$ C31 may facilitate neuronal death in cooperation with other caspase-cleavable death effectors. The present findings that $\mathrm{APP} \triangle \mathrm{A} \beta 20$ and $\mathrm{APP} \triangle \mathrm{A} \beta 20 / \mathrm{C} 31$, both of which lack the $\mathrm{A} \beta(1-20)$ region, failed to induce appreciable cell death lead to the speculation that the $\mathrm{A} \beta(1-20)$ region is indispensable for apoptosis by both caspase-dependent and -independent pathways. It might be of particular interest to examine whether such events are actually operative in neurons that are eliminated during nervous system development and under neurodegenerative conditions such as AD.

\section{Materials and Methods}

\section{Recombinant adenoviruses}

Recombinant adenoviruses expressing wild-type APP and its mutants were constructed as previously. ${ }^{10,11}$ Sequences encoding APP mutants were synthesized by polymerase chain reaction 
(PCR)-mediated template modification. PCR was performed using primers carrying mutated sequences and restriction site (Bgll, Sall) at the ends and human full-length APP695 cDNA as a template. ${ }^{6,37}$ To construct cDNA of $A \beta(1-20)$-lacking APP (APP $\triangle \mathrm{A} \beta 20)$, a PCR product lacking $A \beta(1-20)$ region was inserted between $B g / l l$ and Sall sites of APP695 cDNA. To construct APP $\triangle$ C31, a sequence corresponding APP (amino acids 576-664) was amplified by PCR with a primer that carries two stop codons at the $3^{\prime}$ end and inserted in APP cDNA. APP $\triangle \mathrm{A} \beta 20$ and APP $\triangle \mathrm{cC} 31$ DNAs were fully sequenced, blunt-ended, and subcloned at the Swal site of pAxCAwt. Cosmid DNA was cotransfected with the EcoT221digested DNA-terminal protein complex of Ad5-dIX into 293 cells to generate recombinant viruses by homologous recombination. Adenovirus vectors expressing wild-type APP, APP $\triangle \mathrm{A} \beta 20$, and $\mathrm{APP} \triangle \mathrm{C} 31$ were designated as AxCAYAP, $\operatorname{AxCAP} \triangle \mathrm{A} \beta 20$, and AxCAP $\triangle \mathrm{C} 31$, respectively. Adenovirus expressing $\beta$-galactosidase ( $\beta$-Gal) (AxCALacZ) was provided by Dr. I Saito (University of Tokyo, Tokyo, Japan). Propagation, and titration of recombinant adenoviruses were performed as described previously. ${ }^{10,11}$ Experiments using recombinant adenoviruses were approved by the Recombinant DNA Committee of the Osaka University and performed according to the institutional guidelines.

\section{Adenovirus infection into cultured cells}

Human embryonal carcinoma cells of NTera2/cl.D1 (NT2) cell line 38 (Stratagene, La Jolla, CA, USA) were cultured and neurally differentiated as reported previously. ${ }^{11,39}$ Briefly, NT2 cells were treated with $10 \mu \mathrm{M}$ all-trans retinoic acid (Sigma, St. Louis, MO, USA) for 30 days and subcultured at $\sim 3.0 \times 10^{5}$ cells per $35 \mathrm{~mm}$ dish at $37^{\circ} \mathrm{C}$ and $5 \% \mathrm{CO}_{2}$ in the medium Opti-MEM (Life Technologies, Grand Island, NY, USA) supplemented with $10 \%$ fetal calf serum (FCS) containing $1 \mu \mathrm{M}$ cytosine arabinoside (Sigma) to obtain enriched postmitotic neurons. Serum-deprived neuronal cultures were obtained by incubating neurons in the absence of FCS for $96 \mathrm{~h}$. COS-1 cells, human Bu17 glioma cells, and HeLa cells were cultured in the medium Dulbecco's modified Eagle medium supplemented with 10\% FCS. NT2 neurons and other cells were exposed to recombinant adenovirus vectors at $2 \times 10^{7} \mathrm{pfu} / \mathrm{ml}$ culture medium for $12 \mathrm{~h}$ (multiplicity of infection 25-50) and then incubated in a virus-free fresh medium up to 96 h. $^{11}$

\section{Antibodies}

End-specific antibodies against activated caspase-3 p20/p17 subunits (ACP3), APP $\triangle \mathrm{C} 31$ (SAC), and APP-C31 (ACT1) were raised in rabbits against synthetic peptides corresponding to the caspase-3 cleavage site, ${ }^{40}$ APP $658-664$ of APP695, ${ }^{15}$ APP $665-$ 670 of APP695, respectively. Immunoglobulins G (IgGs) of SAC and ACT1 were depleted of $\lg$ recognizing a bridging peptide corresponding to APP (amino acids 657-670) that spans the caspase cleavage site by affinity chromatography (ProtOn Kit1, Multiple Peptide Systems, San Diego, CA, USA). End-specific reactivities of the antibodies ACP3, SAC, and ACT1 were confirmed by ELISA titration, Western blotting analysis, and immunocytochemistry. Other antibodies used are: a mouse monoclonal antibody against MAP2 (Chemicon, Temecula, CA, USA); a rabbit polyclonal antibody against $\beta$-Gal (Cappel, Aurora, $\mathrm{OH}$, USA); a mouse monoclonal antibody P2-1 against the $\mathrm{N}$ terminus of $\operatorname{APP}^{41}$ (a gift from Dr. Van Nostrand); a rabbit polyclonal antibody against APP (amino acids 671-695) (AC1); ${ }^{6}$ a rabbit polyclonal antibody against APP (amino acids 18-38) (AN2).

\section{Immunocytochemistry}

NT2 neurons and other cells grown on coverslips were fixed $48-72 \mathrm{~h}$ after adenovirus infections with $4 \%$ formaldehyde in phosphatebuffered saline (PBS) $\left(\mathrm{pH} \mathrm{7.4)}\right.$ ) at $4^{\circ} \mathrm{C}$ for $20 \mathrm{~min}$ and permeabilized with acetone at $-20^{\circ} \mathrm{C}$ for $20 \mathrm{~min}$. Then, fixed cells were incubated with primary antibodies in PBS containing $0.05 \%$ Tween 20 at $4{ }^{\circ} \mathrm{C}$ overnight. The cells were then incubated at room temperature for $1 \mathrm{~h}$ with anti-rabbit and anti-mouse IgGs conjugated with fluorescein isothiocyanate (FITC) or rhodamine (Cappel). For chromosomal DNA staining, cells were incubated with $5 \mu \mathrm{M}$ Hoechst 33342 (Sigma) in PBS at room temperature for $10 \mathrm{~min}$. Nuclear DNA fragmentation was analyzed by the TUNEL method. ${ }^{42}$ combined with immunostaining for APP with P2-1. TUNEL reactivity and APP were visualized with Texas Red and FITC, respectively. For caspase-3 inhibitor protection analysis, NT2 neurons were preincubated for $1 \mathrm{~h}$ with DMSO vehicle or Z-DEVD-FMK (Caspase-3 Inhibitor II; Calbiochem, La Jolla, CA, USA), infected with adenoviruses, and cultured for $72 \mathrm{~h}$. After fixation, NT2 neurons were immunostained for APP $\triangle$ C31 with SAC and for APP-C31 with ACT1. Immunoreactive images were observed by fluorescence microscopy (BX50-34-FLAD1, Olympus, Tokyo, Japan).

\section{Cell death analysis}

NT2 neurons and other cells were infected with adenoviruses, and $48 \mathrm{~h}$ or $72 \mathrm{~h}$ later the cells were incubated with $10 \mu \mathrm{M}$ EthD-1 (Molecular Probes, Eugene, OR, USA) in PBS at $37^{\circ} \mathrm{C}$ for $30 \mathrm{~min}$. After fixation, the cells were incubated with the antibody P2-1 against the $\mathrm{N}$ terminus of APP and anti- $\beta$-Gal antibody, and subsequently incubated with FITC-conjugated anti-mouse and anti-rabbit IgGs, respectively. EthD-1-positive cells among 100-200 APP- and $\beta$-Gal-positive cells were counted by choosing five random fields per each dish and expressed as a percentage. Statistical significance was tested using Student's $t$-test.

\section{Cross-linking of cell surface proteins}

NT2 neurons were infected with adenoviruses. The cells were washed $24 \mathrm{~h}$ later with a buffer containing $137 \mathrm{mM} \mathrm{NaCl}, 5.3 \mathrm{mM} \mathrm{KCl}, 170 \mu \mathrm{M}$ $\mathrm{Na}_{2} \mathrm{HPO}_{4}, 220 \mu \mathrm{M} \mathrm{KH} \mathrm{PO}_{4}, 10 \mathrm{mM}$ HEPES, (pH 7.3), $33 \mathrm{mM}$ glucose, and $44 \mathrm{mM}$ sucrose and incubated with $1 \mathrm{mg} / \mathrm{ml}$ bis (sulfosuccinimidyl) suberate (Pierce, Rockford, IL, USA) in the buffer for $30 \mathrm{~min}$ at $37^{\circ} \mathrm{C}$. After cross-linking, neurons were harvested, and their lysates were analyzed by Western blot analysis.

\section{Western blot analysis}

NT2 neurons infected with adenovirus were dislodged by pipetting the medium up and down with a Pasteur pipette several times. Most of the non-neuronal cells remained attached after this treatment. Detached neurons were then collected by centrifugation at $120 \times g$ for $5 \mathrm{~min}$. Enriched neurons were resuspended in the buffer containing $10 \mathrm{mM}$ Tris- $\mathrm{HCl}, \mathrm{pH} 7.4,100 \mu \mathrm{M}$ phenylmethanesulfonyl fluoride, $10 \mu \mathrm{M}$ pepstatin, $10 \mu \mathrm{M}$ leupeptin, and $2 \mu \mathrm{g} / \mathrm{ml}$ aprotinin. The homogenates were centrifuged at $15000 \times \mathrm{g}$ for $30 \mathrm{~min}$, and proteins ( $\mu \mathrm{g}$ per lane) in the pellets (membrane fraction) were separated by $7.5 \%$ SDSpolyacrylamide gel electrophoresis. For analysis of cross-linked cell extracts, $2 \mu \mathrm{g}$ proteins were separated by $6 \%$ SDS-polyacrylamide gel electrophoresis. Proteins were transferred to polyvinylidene difluoride membrane (Millipore, Bedford, MA, USA), and blotted with AC1, AN2, and SAC. The membrane was incubated with peroxidase-labeled antirabbit $\operatorname{lgG}$, and the signals were detected with chemiluminescence reagents (Renaissance Plus; NEN, Boston, MA, USA). 


\section{Measurement of caspase-3-like protease activity}

Adenovirus-infected NT2 neurons were collected and incubated on ice for $10 \mathrm{~min}$ in a cell lysis buffer for caspase activity assay (MBL, Nagoya, Japan). Lysates were centrifuged at $15000 \times g$ for $10 \mathrm{~min}$ at $4^{\circ} \mathrm{C}$, and the supernatant (10 $\mu \mathrm{g}$ protein) was used for caspase-3-like protease assay. Caspase-3-like activity was measured by cleavage of the fluorogenic substrate Z-DEVD-AFC using a kit (FluorAce Apopain kit; Bio-Rad, Hercules, CA, USA) and a spectrofluorometer (VersaFluor; Bio-Rad). One unit was defined as the amount of enzyme required to cleave $1 \mathrm{pmol} A F C$ per 60 min incubation at $37^{\circ} \mathrm{C}$.

\section{COS-1 cytotoxic assay}

cDNA encoding an APP mutant lacking both the $\mathrm{A} \beta(1-20)$ and the Cterminal 31-residue regions (APP $\triangle \mathrm{A} \beta 20 / \mathrm{C} 31$ ) was constructed by $\mathrm{PCR}$ using primers for APP $\triangle \mathrm{C} 31$ and $\mathrm{APP} \triangle \mathrm{A} \beta 20 \mathrm{CDNAs}$ as described above. $\beta$-Gal, wild-type APP, APP $\triangle \mathrm{A} \beta 20$, APP $\Delta \mathrm{C} 31$, and APP $\triangle \mathrm{A} \beta 20 /$ C31 cDNAs were subcloned into pcDNA3.1(+) carrying the cytomegalovirus promoter (Invitrogen, San Diego, CA, USA). Vectors expressing APPs and $\beta$-Gal ( $1 \mu \mathrm{g}$ per assay) were introduced into COS-1 cells using Lipofectamine Plus (Gibco, Gaithersburg, MD, USA), and cell death was analyzed at $72 \mathrm{~h}$ as above.

\section{Acknowledgements}

This work was supported by Health Sciences Research Grants (Research on Brain Science) from the Ministry of Health, Labour and Welfare of Japan (to K Yoshikawa), a grant of Research for the Future from the Japan Society for the Promotion of Science (JSPS) (to K Yoshikawa), and JSPS Research Fellowships for Young Scientists (to I Nishimura). We thank Dr. Izumu Saito for adenovirus vectors and Dr. William Van Nostrand for P2-1 antibody.

\section{References}

1. Glenner GG and Wong CW (1984) Alzheimer's disease: Initial report of the purification and characterization of a novel cerebrovascular amyloid protein. Biochem. Biophys. Res. Commun. 120: 885-890

2. Selkoe DJ (1994) Normal and abnormal biology of the $\beta$-amyloid precursor protein. Annu. Rev. Neurosci. 17: 489-517

3. Yankner BA (1996) Mechanisms of neuronal degeneration in Alzheimer's disease. Neuron 16: 921-932

4. Mattson MP (1997)Cellular actions of $\beta$-amyloid precursor protein and its soluble and fibrillogenic derivatives. Physiol. Rev. 77: 1081-1132

5. Neve RL, McPhie DL and Chen Y (2000) Alzheimer's disease: a dysfunction of the amyloid precursor protein. Brain Res. 886: 54-66

6. Yoshikawa K, Aizawa T and Hayashi Y (1992) Degeneration in vitro of postmitotic neurons overexpressing the Alzheimer amyloid protein precursor. Nature 359: $64-67$

7. Perez RG, Zheng $\mathrm{H}$, Van der Ploeg LH and Koo EH (1997) The $\beta$-amyloid precursor protein of Alzheimer's disease enhances neuron viability and modulates neuronal polarity. J. Neurosci. 17: 9407-9414

8. XuX, Yang D, Wyss-Coray T, Yan J, Gan L, Sun Y and Mucke L (1999) Wild-type but not Alzheimer-mutant amyloid precursor protein confers resistance against p53-mediated apoptosis. Proc. Natl. Acad. Sci. USA 96: 7547-7552

9. Bursztajn S, DeSouza R, McPhie DL, Berman SA, Shioi J, Robakis NK and Neve RL (1998) Overexpression in neurons of human presenilin-1 or a presenilin-1 familial Alzheimer disease mutant does not enhance apoptosis. J. Neurosci. 18: 9790-9799

10. Nishimura I, Uetsuki T, Dani SU, Ohsawa Y, Saito I, Okamura H, Uchiyama Y and Yoshikawa K (1998) Degeneration in vivo of rat hippocampal neurons by wildtype Alzheimer amyloid precursor protein overexpressed by adenovirusmediated gene transfer. J. Neurosci. 18: 2387-2398
11. Uetsuki T, Takemoto K, Nishimura I, Okamoto M, Niinobe M, Momoi T, Miura M and Yoshikawa K (1999) Activation of neuronal caspase-3 by intracellular accumulation of wild-type Alzheimer amyloid precursor protein. J. Neurosci. 19: $6955-6964$

12. Masumura M, Hata R, Nishimura I, Uetsuki T, Sawada T and Yoshikawa K (2000) Caspase-3 activation and inflammatory responses in rat hippocampus inoculated with a recombinant adenovirus expressing the Alzheimer amyloid precursor protein. Brain Res. Mol. Brain Res. 80: 219-227

13. Milligan CE, Prevette D, Yaginuma H, Homma S, Cardwell C, Fritz LC, Tomaselli KJ, Oppenheim RW and Schwartz LM (1995) Peptide inhibitors of the ICE protease family arrest programmed cell death of motoneurons in vivo and in vitro. Neuron 15: 385-393

14. Barnes NY, Li L, Yoshikawa K, Schwartz LM, Oppenheim RW and Milligan CE (1998) Increased production of amyloid precursor protein provides a substrate for caspase-3 in dying motoneurons. J. Neurosci. 18: 5869-5880

15. Gervais FG, Xu D, Robertson GS, Vaillancourt JP, Zhu Y, Huang J, LeBlanc A, Smith D, Rigby M, Shearman MS, ClarkeEE, Zheng H, Van Der Ploeg LH, Ruffolo SC, Thornberry NA, Xanthoudakis S, Zamboni RJ, Roy S and Nicholson DW (1999) Involvement of caspases in proteolytic cleavage of Alzherimer's amyloid$\beta$ precursor protein and amyloidogenic $A \beta$ peptide formation. Cell $97: 395-406$

16. LeBlanc A, LiuH, GoodyerC, Bergeron C and Hammond J (1999) Caspase-6 role in apoptosis of human neurons, amyloidogenesis, and Alzheimer's disease. J. Biol. Chem. 274: 23426-23436

17. Maruyama K, Terakado K, Usami M and Yoshikawa K (1990) Formation of amyloid-like fibrils in COS cells overexpressing part of the Alzheimer amyloid protein precursor. Nature 347: 566-569

18. Pellegrini L, Passer BJ, Tabaton M, Ganjei JK and D'Adamio L (1999) Alternative, non-secretase processing of Alzheimer's $\beta$-amyloid precursor protein during apoptosis by caspase-6 and -8. J. Biol. Chem. 274:21011-21016

19. Weidemann A, Paliga K, Drrwang U, Reinhard FB, Schuckert O, Evin G and Masters CL (1999) Proteolytic processing of the Alzheimer's disease amyloid precursor protein within its cytoplasmic domain by caspase-like proteases. J. Biol. Chem. 274: 5823-5829

20. Lu DC, Rabizadeh S, Chandra S, Shayya RF, Ellerby LM, Ye X, Salvesen GS, Koo EH and Bredesen DE (2000) A second cytotoxic proteolytic peptide derived from amyloid $\beta$-protein precursor. Nat. Med. 6: 397-404

21. Sahara S, Aoto M, Eguchi $Y$, Imamoto N, Yoneda $Y$ and Tsujimoto $Y$ (1999) Acinus is a caspase-3-activated protein required for apoptotic chromatin condensation. Nature 401: 168-173

22. Ohtsubo T, Kamada S, Mikami T, Murakami H and Tsujimoto Y (1999) Identification of NRF2, a member of the NF-E2 family of transcription factors, as a substrate for caspase-3(-like) proteases. Cell Death Differ. 6: 865-872

23. Fasulo L, Ugolini G, Visintin M, Bradbury A, Brancolini C, Verzillo V, Novak M and Cattaneo A (2000) The neuronal microtubule-associated protein tau is a substrate for caspase-3 and an effector of apoptosis. J. Neurochem. 75: 624633

24. Chung CW, Song YH, Kim IK, Yoon WJ, Ruy BR, Jo DG, Woo HN, Kwon YK, Kim HH, Gwag BJ, Mook-Jung IH and Jung YK (2001) Proapoptotic effects of tau cleavage product generated by caspase-3. Neurobiol. Dis. 8: 162-172

25. Trommsdorff M, Borg JP, Margolis B and Herz J (1998) Interaction of cytosolic adaptor proteins with neuronal apolipoprotein $\mathrm{E}$ receptors and the amyloid precursor protein. J. Biol. Chem. 273: $33556-33560$

26. Tominaga K, Uetsuki T, Ogura A and Yoshikawa K (1997) Glutamate responsiveness enhanced in neurones expressing amyloid precursor protein. Neuroreport 8: 2067-2072

27. Games D, Adams D, Alessandrini R, Barbour R, Berthelette P, Blackwell C, Carr T, Clements J, Donaldson T, Gillespie F, Guido T, Hagopian S, Johnson-Wood K, Khan K, Lee M, Leibowitz P, Lieberburg I, Little S, Masliah E, McConlogue L, Montoya-Zavala M, Mucke L, Paganini L, Panniman E, Power M, Schenk D, Seubert P, Snyder B, Soriano F, Tan H, Vitale J, Wadsworth S, Wolozin B and Zhao J (1995) Alzheimer-type neuropathology in transgenic mice overexpressing V717F $\beta$-amyloid precursor protein. Nature 373: 523-527

28. Hsiao K, Chapman P, Nilsen S, Eckman C, Harigaya Y, Younkin S, Yang F and Cole $G$ (1996) Correlative memory deficits, $A \beta$ elevation, and amyloid plaques in transgenic mice. Science 274: 99-102

29. Irizarry MC, Soriano F, McNamara M, Page KJ, Schenk D, Games D and Hyman BT (1997) A $\beta$ deposition is associated with neuropil changes, but not with overt neuronal loss in the human amyloid precursor protein V717F(PDAPP) transgenic mouse. J. Neurosci. 17: 7053-7059 
30. Rohn TT, Ivins KJ, Bahr BA, Cotman CW and Cribbs DH (2000) A monoclona antibody to amyloid precursor protein induces neuronal apoptosis. J. Neurochem. 74: 2331-2342

31. Sudo H, Jiang H, Yasukawa T, Hashimoto Y, Niikura T, Kawasumi M, Matsuda S Takeuchi Y, Aiso S, Matsuoka M, Murayama Y and Nishimoto I (2000) Antibodyregulated neurotoxic function of cell-surface $\beta$-amyloid precursor protein. Mol. Cell. Neurosci. 16: $708-723$

32. Stephenson DT, Rash K and Clemens JA (1992) Amyloid precursor protein accumulates in regions of neurodegeneration following focal cerebral ischemia in the rat. Brain Res. 593: 128-135

33. Saido TC, Yokota M, Maruyama K, Yamao-Harigaya W, Tani E, Ihara $Y$ and Kawashima S (1994) Spatial resolution of the primary $\beta$-amyloidogenic process induced in postischemic hippocampus. J. Biol. Chem. 269: 15253-15257

34. Benowitz LI, Rodriguez W, Paskevich P, Mufson EJ, Schenk D and Neve RL (1989) The amyloid precursor protein is concentrated in neuronal lysosomes in normal and Alzheimer disease subjects. Exp. Neurol. 106: 237-250

35. Cole GM, Masliah E, Shelton ER, Chan HW, Terry RD and Saitoh T (1991) Accumulation of amyloid precursor fragment in Alzheimer plaques. Neurobiol. Aging 12: 85-91

36. Cummings BJ, Su JH, Geddes JW, Van Nostrand WE, Wagner SL, Cunningham DD and Cotman CW (1992) Aggregation of the amyloid precursor protein within degenerating neurons and dystrophic neurites in Alzheimer's disease. Neuroscience 48: 763-777
37. Kang J, Lemaire HG, Unterbeck A, Salbaum JM, Masters CL, Grzeschik KH, Multhaup G, Beyreuther K and Müller-Hill B (1987) The precursor of Alzheimer's disease amyloid A4 protein resembles a cell-surface receptor. Nature 325: 733 736

38. Andrews PW (1984) Retinoic acid induces neuronal differentiation of a cloned human embryonal carcinoma cell line in vitro. Dev. Biol. 103: 285-293

39. Pleasure SJ, Page $C$ and Lee VM (1992) Pure, postmitotic, polarized human neurons derived from NTera2 cells provide a system for expressing exogenous proteins in terminally differentiated neurons. J. Neurosci. 12: 1802-1815

40. Kouroku Y, Urase K, Fujita E, Isahara K, Onsawa Y, Uchiyama Y, Momoi MY and Momoi T (1998) Detection of activated Caspase-3 by a cleavage site-directed antiserum during naturally occurring DRG neurons apoptosis. Biochem. Biophys. Res. Commun. 247: 780-784

41. Van Nostrand WE, Wagner SL, Suzuki M, Choi BH, Farrow JS, Geddes JW, Cotman CW and Cunningham DD (1989) Protease nexin-II, a potent antichymotrypsin, shows identity to amyloid $\beta$-protein precursor. Nature 341 : 546-549

42. Gavrieli Y, Sherman Y and Ben-Sasson SA (1992) Identification of programmed cell death in situ via specific labeling of nuclear DNA fragmentation. J. Cell Biol. 119: 493-501 